\title{
Kentsel Planlamada İklim Direnci Teması; Ankara Örneği
}

\author{
Gizem KARACAN ${ }^{1}$, Duygu GÖKCE ${ }^{2}$
}

\section{Öz}

Kentler, iklimsel, coğrafi, mekânsal ve sosyo-ekonomik yapı özelliklerine bağlı olarak gelecekte farklı iklim değişikliği risk ve tehditleriyle karşı karşıya kalacaktır. İklim değişikliğinin kentlerin ekosistemi, yaşayanları, ekonomisi, fiziki çevresi ve altyapısı üzerinde olumsuz etkilerinin olacağı öngörülmektedir. Makalede, kentlerin ya da kentsel sistemlerin söz konusu risk, tehdit ve olumsuz etkilerle başa çıkabilmesi için son dönemde planlama yazınında da öne çıkan "dirençlilik" düşünce ya da temasının benimsenmesi gerektiği vurgulanmaktadır. İklim değişikliğinden kaynaklı belirsizliklere ve beklenmedik gelişmelere karşı dirençli kentler inşa edebilmek için, hem iklim değişikliği risk, tehdit ve etkilerinin azaltılması / hafifletilmesi (böylece sistemin sağlamlığının arttıııması) hem de uyumun sağlanması (sistemin kendini düzeltme hızının artııılması) gereklidir. Nitekim ilgili yazında da, iklim dirençli kentler inşa edebilmek için iklim değişikliği azaltım ve adaptasyon politikalarının birlikte ele alınması ve bunların kentsel arazi kullanım politika ve planlarıyla bütünleştirilmesi gerektiği savunulmaktadır. Ancak azaltım ve adaptasyon politika ve stratejileri kimi zaman birbiriyle çelişebilmektedir. Bu durumda bir kent için azaltım ve adaptasyon politika veya stratejilerinden hangisinin öncelikli olacağına karar verilmelidir. Kararda ise, o kentin fiziksel, çevresel, morfolojik ve sosyo-ekonomik yapı özellikleri belirleyicidir. Makalede, Ankara kenti çalışma alanı olarak belirlenmiştir. Ankara kentinin fiziksel, çevresel, morfolojik ve sosyo-ekonomik özellikleri incelenerek hangi iklim değişikliği politikasına öncelik verilmesi gerektiği ortaya konulacak, sonrasında Ankara Çevre Düzeni Planı ve Nazım İmar Planı hedef ve politikaları, Ankara'nın iklim dirençli inşası açısından değerlendirilecektir.

Anahtar Kelimeler: İklim değişikliği, İklim direnci, Azaltım, Kentsel planlama, Ankara.

\section{Climate Resilience Theme in Urban Planning; Case of Ankara}

\begin{abstract}
Depending on the climatic, geographical, spatial and socio-economic characteristics of cities, cities will face different climate change risks and threats in the future. It is predicted that climate change will have negative effects on the ecosystem, inhabitants, economy, physical environment and infrastructure of cities. In this paper, it is emphasized that in order to cope with these risks, threats and negative effects, cities or urban systems should adopt the idea or theme of resilience which is prominent in the planning literature. In order to build cities that are resistant to uncertainties and unexpected developments from climate change, both mitigating / mitigating the risks, threats and impacts of climate change (thereby increasing the robustness of the system) and adapting (increasing the system's self-correction rate) are essential. As a matter of fact, in the related literature, it is argued that climate change mitigation and adaptation policies should be handled together and integrated with urban land use policies and plans in order to build climate resistant cities. However, mitigation and adaptation policies and strategies may sometimes contradict each other. In this case, one of the mitigation and adaptation policies or strategies should be decided for a city. In the decision, physical, environmental, morphological and socio-economic characteristics of the city are decisive. In the decision, the physical, environmental, morphological and socio-economic structure characteristics of
\end{abstract}

\footnotetext{
${ }^{1}$ Süleyman Demirel Üniversitesi Fen Bilimleri Enstitüsü, Mimarlık, Planlama ve Tasarım Ana Bilim Dalı, Isparta

${ }^{2}$ Süleyman Demirel Üniversitesi Mimarlık Fakültesi, Şehir ve Bölge Planlama Bölümü, Isparta

*ilgili yazar / Corresponding author: karacangzm@gmail.com
}

*Bu makale, 26-28 Haziran 2019 tarihleri arasında Eskişehir Teknik Üniversitesi'nde düzenlenen "Uluslararası Afet ve Direnç Kongresi-Riskten Dirençliliğe" adı etkinlikte sözlü bildiri olarak sunulmuștu . Gönderim Tarihi / Received Date: 22.04.2020

Kabul Tarihi / Accepted Date: 19.11.2020 
that city are decisive. In the article, the city of Ankara is determined as the study area. The physical, environmental, morphological and socio-economic characteristics of the city of Ankara will be examined, which climate change policy should be prioritized, and then the Ankara Environmental Plan and Master Plan will be evaluated in terms of Ankara's climate-resistant construction.

Keywords: Climate change, Climate resilience, Mitigation, Urban planning, Ankara.

\section{GíRiş}

Aşırı hava olayları olarak tanımlanan iklim değişikliği ile birlikte; sıcak hava dalgaları, deniz seviyesinde yükselme, şiddetli fırtına dalgalanmaları, sel, taşkın, kuraklık, orman yangınları, tarımsal verimsizlik, biyoçeşitliliğin azalması gibi risk ve tehditler öngörülmektedir. Küresel iklimde yaşanan değişiklikler doğal (canlıların yaşamı, su döngüleri) ve yapılı çevre (altyapının ve binaların zarar görmesi) üzerinde çeşitli olumsuz etkiler yaratabilmektedir. İklim değişiminin etkileri üzerine yapılan çalışmalar, iklim değişikliklerinin farklı sektör ve ülkeler üzerinde, farklı etkilere sahip olduğunu göstermektedir. Gelişmekte olan ülkeler gelişmiş ülkelere göre iklim değişikliğinden daha fazla etkilenmektedir (Nordhaus, 1993).

İklim değişikliğinin çevresel ve sosyo-ekonomik boyuttaki etkileri de ülkelerin gelişmişlik düzeylerine ve kentlerin kırılganlık düzeylerine göre farklılıklar göstermektedir. Bu bağlamda, yerel ölçekte de her kentin fiziksel, çevresel, sosyo-ekonomik ve morfolojik özelliklerinin ne olduğu, diğer bir ifadeyle, hangi iklim değişikliği risk ve tehditleriyle karşı karşıya kaldığı ya da kalacağı, doğal çevre, yapay çevre ve insanlar üzerindeki olası olumsuz etkileri, kentin morfolojik yapısından kaynaklı sera gazı üretme durumu ve iklim değişikliğine karşı dirençlilik gücünün ne olduğu gibi hususların bilinmesi önem arz etmektedir.

Bu kapsamda makalede, öncelikle dirençlilik kavramı ele alınacak, ardından, Ankara kentinin fiziksel, çevresel, morfolojik ve sosyo-ekonomik özellikleri incelenerek kentin iklim değişikliğine karşı dirençli olabilmesi için yerel ölçekte hangi iklim değişikliği politikasına öncelik verilmesi gerektiği ortaya konulacak, son olarak, iklim politikalarının kent planlamayla entegrasyonunun sağlanması gerekliliğinden hareketle, Ankara Çevre Düzeni Planı ve Nazım İmar Planı hedef ve politikaları, Ankara'nın iklim dirençli inşası açısından değerlendirilecektir.

\section{DIRENÇLILIKK KAVRAMI}

Dirençlilik kavramına ve daha özelde kentsel dirençlilik kavramına, ilgili literatürde ve politika söylemlerinde artan bir ilgi bulunmaktadır. Genel olarak dirençlilik kavramı, bir sistemin beklenmedik rahatsızlıklarla baş etmesi, kendini yenileyebilmesi ve temel fonksiyonlarını sürdürebilmesi olarak tanımlanmaktadır. Kentsel sistemlerin küresel ekolojik sorunlar ve afetler karşısında kırılganlığı artmaktadır. Kentlerin artan bu tür kaygılar (örneğin, iklim değişikliği) karşısında nasıl daha dirençli olabileceği üzerine plan ve politikalar geliştirilmektedir. Godschalk (2003), risklere karşı daha dirençli kentler (kentsel sistemler) yaratmak için kentlerin sekiz bileşenini tanımlamıştır.

- Çokluk (Redundancy): İşlevsel olarak benzer bileşenlerin geliştirilmesi; bu şekilde bir bileşen zarar gördüğünde tüm sistemin zarar görmemesi,

- Çeşitlilik (Diversity): Sistemi çeşitli tehditlere karşı korumak için işlevsel olarak farklı bileşenler içermesi,

- Verimlilik (Efficieny): Dinamik bir sistem tarafından sağlanan enerji arzı,

- Yetkinlik (Autonomy): Dış kontrolden bağımsız olarak çalışabilme özelliğine sahip olması,

- Güç (Strength) : Bir saldırıya veya diğer dış güçlere direnme gücü, 
- Birbirine bağımlılık (Interdependent): Sistem bileşenlerinin birbirlerini destekleyecek şekilde bağlı olması,

- Uyum gösterme (Adaptability): Deneyimden öğrenme kapasitesi ve değiştirme direnci olması,

- İşbirliği (Collaboration): Geniş paydaş katıımı için birden fazla fırsat ve teşvik içermesi.

Benzer şekilde Albers ve Deppisch (2013), kentsel ve bölgesel dirençliliğin ilkelerini şematize etmiştir (Şekil 1).

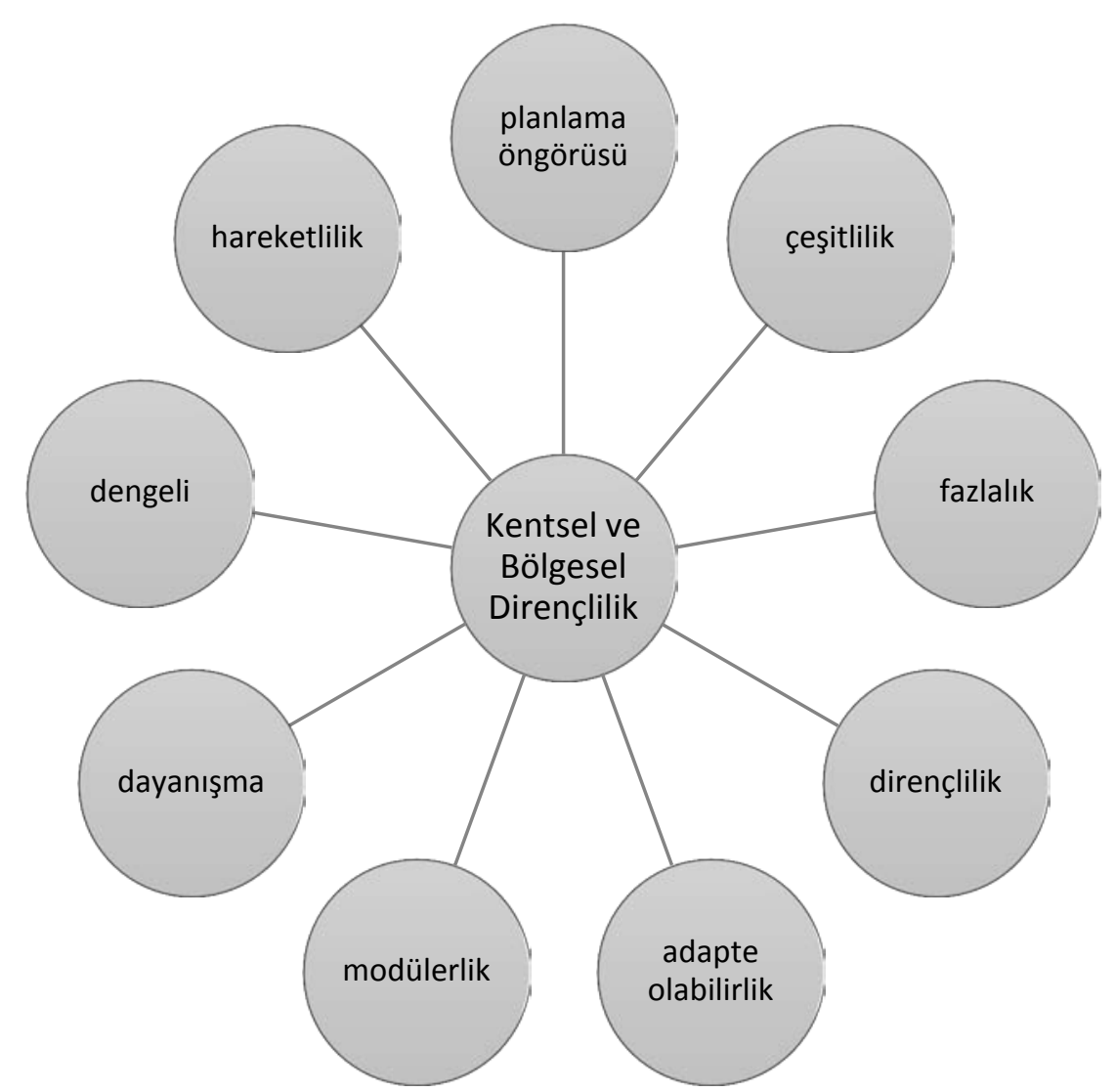

Şekil 1. Kentsel ve bölgesel dirençlilik ilkeleri (Albers ve Deppisch, 2013)

Normandin vd (2009), dirençlilik kavramını dört seviyeli bir "Dirençlilik Bağlantılı Yaklaşım" olarak örneklendirmiştir. Bu modelde dört seviye birbirleriyle etkileşim halindedir. Örneğin kent konseyi (yönetişim) yeni bir bina kodu veya yeni bir ulaşım planı oluşturarak yapılı çevreyi etkileyebilmektedir. Model için geliştirilen şemada yer alan kategorilerin birbirlerini dışlamadığı görülmektedir (Şekil 2). 


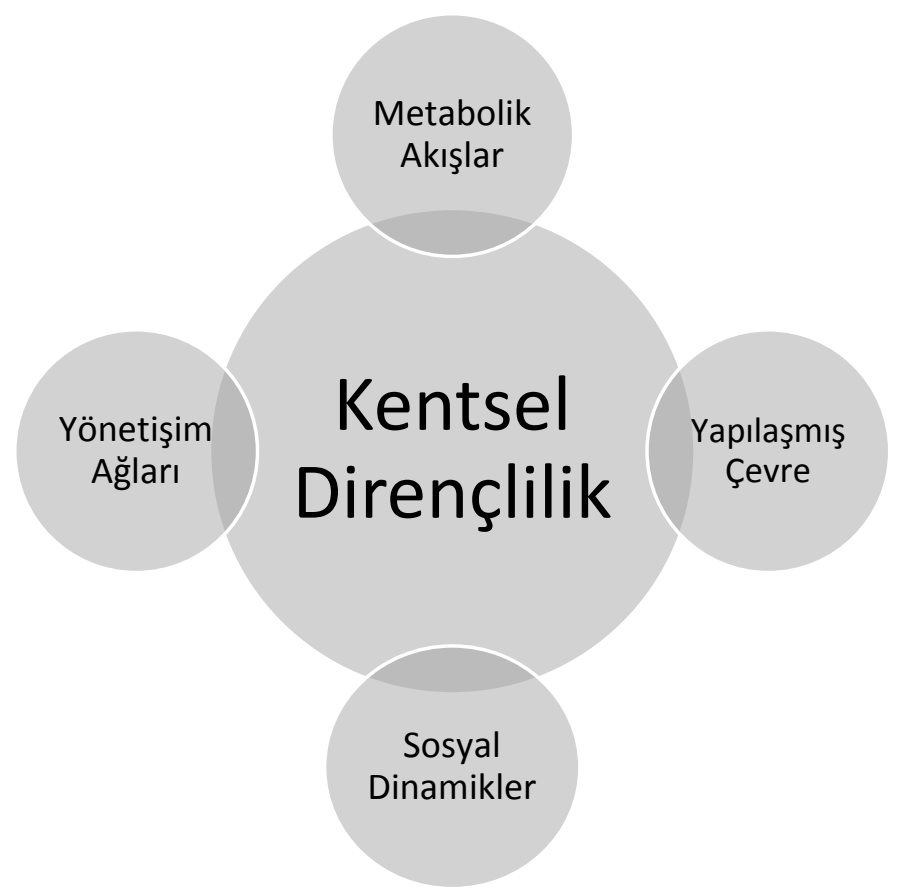

Şekil 2. Kentsel dirençliliğin dört bileşeni (Normandin vd. 2009)

Dirençlilik Bağlantılı Yaklaşım'da şehirler bir sosyo-ekolojik sistem olarak temsil edilmektedir. Metabolik akışlar kavramı kentin sınırlarını aşan ekosistemlerdeki üretim, tüketim ve tedarik zincirlerini temsil etmektedir. Bu da nüfusun refahı ve toplumun yaşam kalitesi için gerekli olan enerji, maddi mallar ve hizmetleri içermektedir.

Sosyal dinamikler kavramı demografik özellikleri, beşeri sermayeyi ve nüfusun eşitsizliğini içermektedir.

Yönetişim ağları kavramı kenti yöneten kurum ve kuruluşlardan oluşmaktadır. Kurumların aralarındaki bağlar bölgesel, ulusal ve uluslararası düzeylerdeki ilişkilerden oluşmaktadır. Yönetişim ayrıca bütçe ve hizmetlerin (altyapı, eğitim, güvenlik vb.) idaresini de karakterize etmektedir.

Yapılaşmış çevre kavramı farklı ekolojik çevreler ile kentsel peyzajları ve habitatları temsil etmektedir. Politikalar, bina kodları ve taşımacılık aktiviteleri yapılaşmış çevrenin gelişimini etkilemektedir (Normandin, vd., 2009).

Farklı disiplinler arasında dirençliliğin nasıl tanımlanacağı ve ölçüleceği konularında ortak noktalar olmasa da, kentlerin iklim değişikliğine karşı dirençli hale gelmesi gerektiği ve dirençliliği arttırma çabaları birlikte ele alınmaktadır (Leichenko, 2011). Kentsel dirençlilik ölçeklere göre farklılıklar göstermektedir. Dirençlilik, kentsel alanların dirençliliğinin derecesinin değerlendirilmesi olarak görülebilir. Örneğin Sharifi ve Yamagata (2014), kentsel dirençliliğin değerlendirmesinde kullanılabilecek bazı önemli kriterler (Tablo 1) belirlemiştir. 
Tablo 1. Kentsel dirençliliğin değerlendirilmesinde kullanılabilecek bazı önemli kriterler (Sharifi ve Yamagata, 2014)

\begin{tabular}{|c|c|c|}
\hline Tema & Alt tema & Kriterler \\
\hline \multirow[t]{9}{*}{ Altyapı } & Su & $\begin{array}{l}\text { Geçirgen kaldırım ve biyoseller, kentsel gölgelik alanlar, su talebi } \\
\text { ve tüketimi, suya duyarlı alanların korunması, su miktarı ve } \\
\text { kalitesinin izlenmesi }\end{array}$ \\
\hline & Enerji & $\begin{array}{l}\text { Enerji talebi ve tüketimi, şebekenin direnci, yenilenebilir enerji } \\
\text { paylarını artırmak için kentsel enerji tedarik sistemleri }\end{array}$ \\
\hline & $\begin{array}{l}\text { Mekansal } \\
\text { yapılandırma ve } \\
\text { konum }\end{array}$ & $\begin{array}{l}\text { Sokak bağlantısı, yaya yolu bağlantısı, toplu taşıma yollarıyla } \\
\text { bağlantılı yürüyüş yolları, tahliye yollarına erişilebilir bağlantı, } \\
\text { kentsel form (kompakt, dağınık, çok merkezli), bina yoğunluğu, } \\
\text { kentsel boyut ve yükseklik }\end{array}$ \\
\hline & Taşımacılık & Yüksek frekans tarifeli toplu taşıma, araç sahipliği, \\
\hline & Yeşil Altyapı & Parklar, ormanların korunması, atık yönetimi \\
\hline & Savunma yapıları & Kıyı savunma yapıları (eşikler, kumullar vb.) \\
\hline & Barınma & $\begin{array}{l}\text { Barınak için açık alan sağlanması, boş kiralık birimlerin yüzdesi, } \\
\mathrm{km}^{2} \text { başına otel / motel sayısı, tahliye yolları, }\end{array}$ \\
\hline & Bina ve tasarım & $\begin{array}{l}\text { Bina yalıtımı, bina yerleşimi ve yönlendirmesi, doğal } \\
\text { havalandırma, konutların korunması, konut yaşı, }\end{array}$ \\
\hline & Teknoloji ve bilgi & $\begin{array}{l}\text { Bilgi üretme ve kullanma, coğrafi bilgi ve iletişim teknolojisi, } \\
\text { coğrafi bilgi üretkenliği, yenilik, veri kullanılabilirliği, görüntüleme } \\
\text { teknolojileri, uyarılar ve acil durum bildirim sistemleri, }\end{array}$ \\
\hline Güvenlik & & $\begin{array}{l}\text { Savunabilir alanlar, güvenlik altyapısının görünürlüğü, şehir } \\
\text { çapında gözetim ağları, biyometrik sınırlar, gözetim kameraları, }\end{array}$ \\
\hline Çevre & Ekosistem & $\begin{array}{l}\text { Biyoçeşitlilik, hidrolojik akışların restorasyonu, ekolojik açıdan } \\
\text { savunmasız alanların korunması, erozyon oranları, }\end{array}$ \\
\hline Ekonomi & & $\begin{array}{l}\text { Kendi kendine yeterlilik, kentsel tarım, kentsel yeşil ortak alanlar, } \\
\text { finansal destek, finansal istikrar ve dirençlilik, sigorta ve tazminat } \\
\text { sistemi, çeşitlendirilmiş geçim kaynakları, ürün hizmet sistemleri, } \\
\text { bölgesel ekonomik denge, vergilendirme ve maliye politikaları, } \\
\text { kişisel ekonomik güvenlik, konut sakinlerinin iş çeşitliliği, konut } \\
\text { sermayesi, istihdam, turistik cazibe, iş büyüklüğü, }\end{array}$ \\
\hline \multirow[t]{2}{*}{ Kurumlar } & Planlama & $\begin{array}{l}\text { İmar yönetmelikleri (tehlikeye yatkın alanlarda gelişme } \\
\text { yoğunluğu), riskleri ve kırılganlıkları dikkate alan alt bölümler, } \\
\text { tehlike bölgelerinin insanlar tarafından işgal edilmesi, tehlike } \\
\text { analizi ve tehlike haritalarının oluşturulması, senaryoya dayalı } \\
\text { planlama, itme ve çekme faktörleri, işbirlikçi planlama, proaktif } \\
\text { planlama, dirençlilik düzeyi, arazi ve mülk edinme, }\end{array}$ \\
\hline & Hükümet & $\begin{array}{l}\text { Merkezi yönetim yaklaşımı, karbon fiyatlandırması, halkın } \\
\text { katıımı, belli bir hesap verebilirlik ve özerklik, kişilerarası ve } \\
\text { kurumlar arası güven, kurumlar arası işbirliği, siyasi istikrar, } \\
\text { liderliğin gücü, tahliye ve acil durum yönetimi tatbikatları, farklı } \\
\text { düzeylerde şehir ağı (bölgesel, ulusal, ulus ötesi), şeffaflık }\end{array}$ \\
\hline \multirow[t]{2}{*}{$\begin{array}{l}\text { Sosyal ve } \\
\text { demografik özellikler }\end{array}$} & & $\begin{array}{l}\text { İşbirliği kültürü, dengeli demografik dağılım, nesiller arası bağlar, } \\
\text { kültürel çeşitlilik, sosyal uyum, öz örgütlenme, eğitim, farkındalık } \\
\text { düzeyi, yüz yüze etkileşim oranı, yoksulluk oranı, sosyal ağlar, } \\
\text { gelir düzeyi, yaşlanan nüfus }\end{array}$ \\
\hline & Sağlık & Duyarlı sağlık sistemleri, sağlık kapsamı, sağlığa erişim, \\
\hline
\end{tabular}

Makalede, iklim değişikliği risklerine karşı daha dirençli kentler inşa edebilmenin, iklim değişikliği azaltım ve adaptasyon politikalarının kentsel planlamaya entegrasyonuyla sağlanabileceğini, bu doğrultuda, iklim değişikliği tehdit ve etkilerine uyum sağlamayı destekleyen arazi kullanım politikaları ve arazi kullanım planlamasının gerekliliği savunulmaktadır. Ancak, iklim değişikliği azaltım ve adaptasyon politikalarının kimi zaman birbiriyle çelişebildiği de göz önüne alındığında, her kentin yerel özelliklerinin politikaların önceliği üzerinde belirleyici olacağı söylenebilir. 


\section{ANKARA KENTI IÇíN AZALTIM POLITIKA VE STRATEJILERININ ÖNEMI}

İklim değişikliğinden kaynaklı belirsizliklere ve beklenmedik gelişmelere karşı dirençli kentler inşa edebilmek için, hem iklim değişikliği risk, tehdit ve etkilerinin azaltılması / hafifletilmesi (böylece sistemin sağlamlığının arttırılması) hem de uyumun sağlanması (sistemin kendini düzeltme hızının arttırılması) gereklidir (Denton, vd. 2014). Azaltım, iklim değişikliğinin nedenlerine odaklanarak bu nedenleri azaltmayı ve kontrol altına almayı (sera gazı emisyonlarını azaltma veya karbon depolama kapasitesini artırma çabalarını) amaçlarken; adaptasyon, iklim değişikliği sonuçlarına odaklanarak olası iklim değişikliği risk ve tehditlerine karşı hazırıklı olmayı, uyum kapasitesini arttırmayı amaçlar. Ancak azaltım ve adaptasyon politika ve stratejileri kimi zaman birbiriyle çelişebilmektedir. Örneğin Hamin ve Gurran (2009), yaptıkları çalışmayla azaltım ve adaptasyon stratejilerinin bir kısmının birbiriyle çeliştiğini tespit etmişlerdir. Örneğin, sera gazı azaltım stratejileri daha yoğun, kompakt bir kentsel form ve arazi kullanımına; adaptasyon stratejileri ise daha düşük yoğunluklu ve açık alanlardan oluşan boşluklu bir kentsel yapıya işaret etmektedir.

$\mathrm{Bu}$ durumda bir kent için azaltım ve adaptasyon politika veya stratejilerinden hangisinin öncelikli olacağına karar verilmelidir (Sılaydın ve Kahraman, 2017). Kararda ise, o kentin fiziksel, çevresel, morfolojik ve sosyo-ekonomik yapı özellikleri belirleyicidir. Bu özellikler azaltım politika ve stratejileri açısından değerlendirildiğinde, kentte sera gazı emisyonuna yol açan faktörleri belirlemek önem arz etmektedir. Fiziksel özellikler; kentin yer aldığı coğrafi konumu ve iklim yapısı iklim değişikliğinden etkilenme biçimi ve büyüklüğü açısından belirleyicidir. Çevresel özellikler; orman alanları, tarım toprakları, sulak alanlar vb. karbon yutak alanlarını oluşturduğu için kentin sera gazı emisyon miktarını azaltmada önemli role sahiptir. Ayrıca kullanılan enerji türü kentin sera gazı emisyonu üzerinde belirleyici roldedir. Morfolojik özellikler ise, kentin salacağı sera gazı miktarını belirlemede önemlidir. Örneğin kentin makroformu, yerleşik alan büyüklüğü ulaşımdan kaynaklı sera gazı miktarına etki ederek sera gazı emisyonlarını arttırabilir veya azaltabilir. Park alanları karbon yutağı olarak salınan karbondioksiti fotosentez yoluyla bağlayarak azaltıma katkıda bulunur. Kent içinde parkların alansal büyüklükleri ve dağılımları kentin doluluk ve boşluk oranını belirlemektedir. Nüfus yoğunluğu, yapı yoğunluğuyla da ilişkili olduğundan ve sera gazı üreten bir faktör olduğundan morfolojik bir özellik olarak değerlendirilebilir. Sosyo-ekonomik-demografik özellikler; tüketim alışkanlıkları, enerji kullanım miktarı ve buna bağlı sera gazı emisyon miktarları üzerinde etkilidir. Nüfus arttıkça enerjiye olan ihtiyaç ve sera gazı emisyonu artmaktadır. Gelir durumu, taşıt sahiplilik oranı ile sera gazı emisyon miktarı arasında da doğru orantılı bir ilişki vardır. Sosyo-ekonomik gelişmişlik düzeyi arttıkça sera gazı emisyon miktarı da artmaktadır.

Söz konusu fiziksel, çevresel, morfolojik ve sosyo-ekonomik yapı özellikleri adaptasyon politika ve stratejileri açısından değerlendirildiğinde, bir kentin kırılganlık düzeyini belirlemek önem arz etmektedir. Kentin hangi iklim değişikliğine dayalı afet tehditleriyle ve bunun olumsuz etkileriyle karşı karşıya kalacağı ve bunlara karşı kentin kırılganlık düzeyinin ne olduğu konusu; kentin coğrafi özellikleri, iklim yapısı, nüfus büyüklüğü, nüfus yoğunluğu, kırılgan/savunmasız nüfus büyüklüğü, gelir durumu ve refah düzeyi, sosyo-ekonomik yapı, kentsel yeşil alan büyüklüğü ve dağıımı, sağlık ve altyapı hizmetlerine erişim, kurumsal yapı gibi çeşitli faktörler bağlamında değerlendirilebilir. Böylece, iklim değişikliğinin olumsuz etkilerine maruz kalacak alan ve nüfus büyüklüğü, geçirimli yüzeylerin büyüklüğü, sosyoekonomik gelişmişlik düzeyi, altyapı hizmetlerine erişim, afet yönetiminin varlığı ve etkinliğine bağlı olarak o kentin afetlerle baş edebilme, afetlere karşı direnç gösterebilme ve olası zararları en kısa sürede telafi edebilme / iyileşebilme kapasiteleri ortaya konulmuş olur.

Makale kapsamında incelenen Ankara kentinin iklim değişikliğinden zarar görebilirliğinin belirlenmesi amacıyla yapılan bir çalışmada (Çobanyılmaz ve Yüksel, 2013), kentte 
meydana gelmesi olası iklim değişiklikleri ve bunlara bağı olarak ortaya çıkabilecek doğal afet tehditlerine kentin hazırlıksız olduğu, kentin yüksek derece zarar görebilir olduğu belirlenmiştir. Dolayısıyla Ankara kenti için iklim değişikliği politikalarından hangisinin öncelikli olması ve kent planlamaya entegre edilmesi gerektiği, kentin fiziksel, çevresel, morfolojik ve demografik-sosyo-ekonomik yapı özellikleri bağlamında değerlendirilebilir.

\subsection{Fiziksel özellikleri}

Ankara kenti, Orta Anadolu'nun kuzeybatısında bulunan Kızılırmak ve Sakarya nehirlerinin kollarının oluşturduğu ovalarla kaplı bir bölgede yer almaktadır. Kuzey sınırında Kuzey Anadolu sıra dağları ile güney sınırında Tuz Gölü çanağı bulunmaktadır (Ankara Büyükşehir Belediyesi, 2017a). Diğer bir ifadeyle, Ankara kenti coğrafi olarak tepelerle çevrelenen bir çanak içerisinde Hatip Ovası üzerinde yer almaktadır (Şekil 3). Kent zaman içerisinde büyüyerek çevresinde yer alan sırtlar üzerinde yayılarak gelişme göstermiştir (Çobanyılmaz ve Yüksel, 2013).

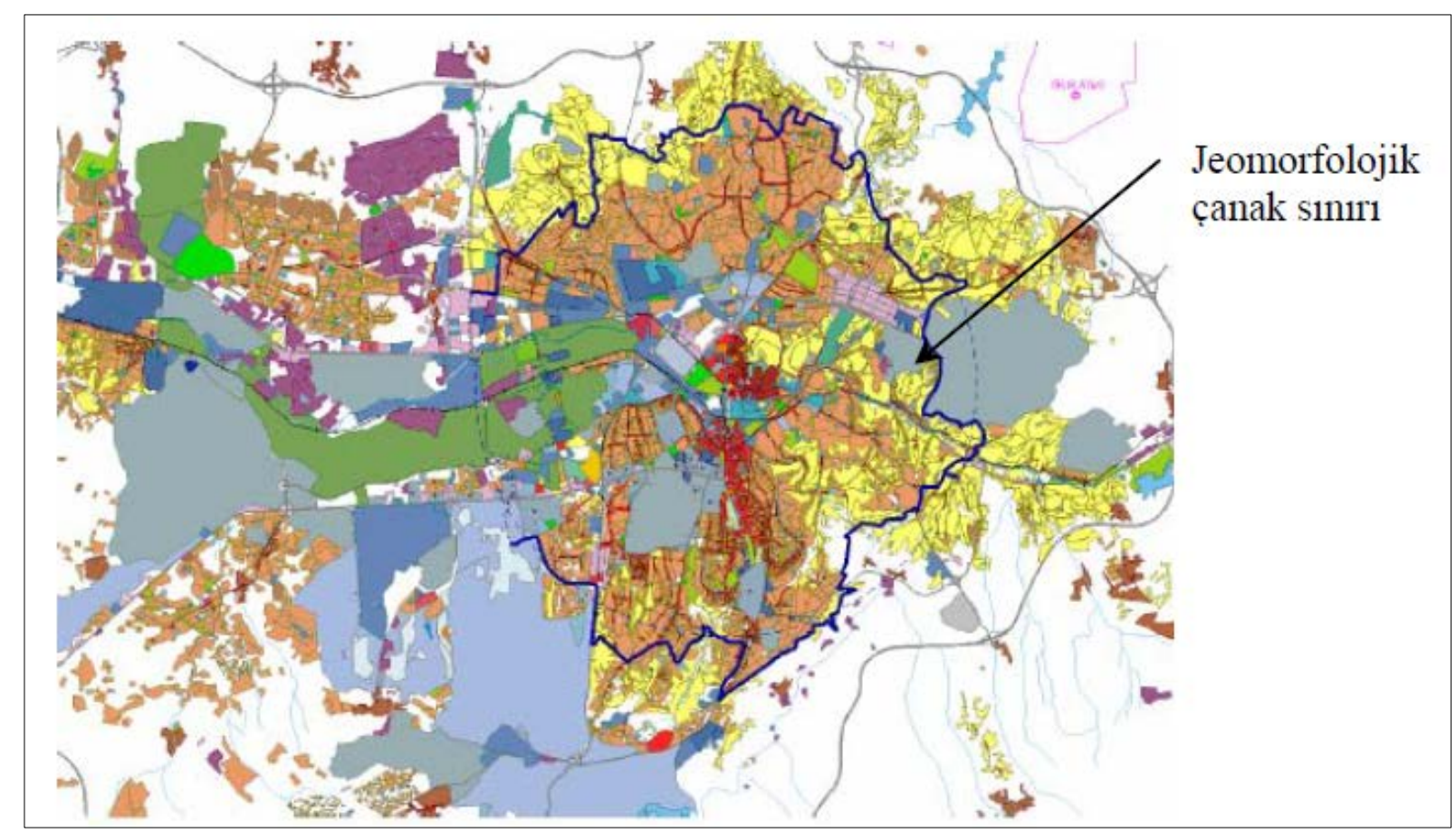

Şekil 1. Ankara kentinin jeomorfolojik çanak sınırı (Yüksel ve Yılmaz, 2008)

Ankara kentinin jeomorfolojik yapısı değerlendirildiğinde, kent merkezinin çukurda kalan bir alanda toplandığı ve çevresine doğru bir yerleşim ağı oluşturduğu görülmektedir. Arazi yapısından kaynaklanan bu çanak modeli yıllar içinde kenti kompakt formdan uzaklaştırıp, yoğun yapılaşmanın bir arada görüldüğü bir forma dönüştürmüştür. Tüm bu sebeplerle kentin etrafında bir çeper meydana gelmiş ve hava akımını engelleyici ısı adası etkisini ortaya çıkarmıştır (ABB, 2007).

Kentin jeolojik ve jeomorfolojik özelliklerine bağlı olarak karasal iklim hakim olmasına rağmen, yer yer farklı iklim türlerinin özellikleri de görülmektedir. İstanbul Teknik Üniversitesi Avrasya Yer Bilimleri Enstitüsü tarafından oluşturulan veri tabanı ile A2 senaryosu, ECHAM5 küresel modeli ve RegCM3 bölgesel modeli kullanılarak hazırlanan Ankara'nın 2011 ve 2050 yılları için sıcaklık ve yağış simülasyon haritalarına göre, Ankara kentinde sıcaklığın 2050 yılına kadar ortalama $3,8^{\circ} \mathrm{C}$ artış göstereceği, yağış miktarında çok az bir azalma meydana geleceği, bununla birlikte, yağış dağılımında değişimlerin yaşanacağı öngörülmektedir (Çobanyılmaz ve Yüksel, 2013). 
Sıcaklık artışı gelecekte öngörülen nüfus artışıyla birlikte değerlendirildiğinde, gelecekte su talebine olan ihtiyacın ve Ankara'da yıllardır yaşanan kuraklık riskini daha da arttıracağı söylenebilir. Kentte meydana gelen ve gelecekte de devam edeceği öngörülen aşırı yağış olayları ise kentin topoğrafik yapısı, kentsel gelişimi, altyapı hizmetlerindeki yetersizlikler birlikte değerlendirildiğinde; kentte gelecekte taşkın, sel ve toprak kayması riskinin artacağı söylenebilir.

\section{2.Çevresel özellikleri}

2014 yılında yayımlanan Çevre ve Şehircilik Bakanlığı Türkiye Çevre Sorunları ve Öncelikleri Envanteri Değerlendirme Raporu'na göre, Ankara'nın birinci öncelikli çevre sorunu hava kirliliğidir. Ankara kent makroformunun gelişiminde önemli bir etken olan ve kentte gözlemlenen hava kirliliği sorunlarının da başlıca sebebini oluşturan coğrafi konumdur. Kent coğrafi konum açısından İç Anadolu havzasında, denizlere kapalı, hava sirkülasyonu oluşturabilecek güçlü rüzgarlardan yoksun bir yapıdadır (ABB, 2007).

Çevre ve Şehircilik Bakanlığı 2017 yılı verilerine göre kentteki ormanlık alan toplamı 2.577.976 hektardır. 2015 yılı sonu itibarıyla ormanlık alan değişimine bakıldığında, 2005 yılından 2010 yılına gelindiğinde ormanlık alan miktarında \%0.7'lik bir artış sağlanmasına rağmen, 2010-2015 yılları arasında \%2.6'lık bir artış gerçekleşmiştir.

Ankara'da fosil yakıt tüketimi incelendiğinde, kullanılan elektriğin üretiminde fosil yakıtların payının \%83.5'lik bir paya sahip olduğu görülmektedir (Ankara Kalkınma Ajansı, 2013a). Ankara'da kullanılan elektrik enerji kaynağı olarak büyük ölçüde doğalgazdan sağlanmaktadır. Güneş, rüzgar, jeotermal ve biyokütle gibi yenilenebilir enerji kaynak potansiyellerinin ise yeterince değerlendirilmediği görülmektedir.

\subsection{Morfolojik özellikleri}

Ankara'da makroformun saçaklanması sonucu kent, tarım arazileri ve su koruma havzaları üzerinde yayılmış, aynı zamanda gidilecek mesafeler uzadığından dolayı araç kullanımı sayısı artmıştır. Ankara kent makroformu bağlamında yıllar geçtikçe merkezden çepere olan mesafe sürekli artış göstermiş, 1924 yılında merkezden çepere mesafe 2 km iken, 1970'te 10 km, 1985 yılında 24 km ve 2005 yılına gelindiğinde bu mesafe 35 km'ye kadar çıkmıştır (Durmaz ve Erçetin, 2012) (Şekil 4). 


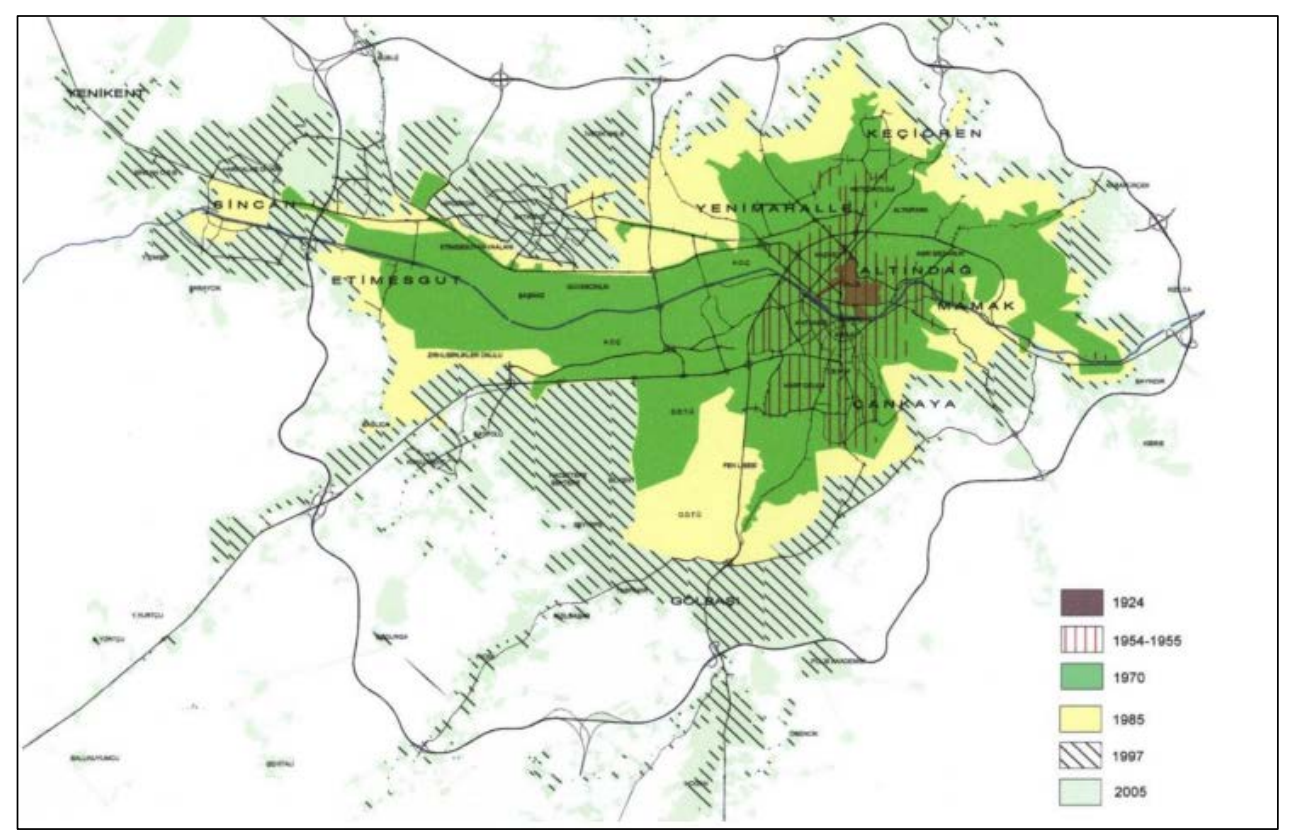

Şekil 2. Ankara kent makroformunun yıllar içindeki değişimi (Ankara Kalkınma Ajansı, 2013b) Ankara kenti yıllar itibariyle hızlı bir nüfus artışı yaşamıştır ve artan nüfusun getirdiği bazı olumsuzluklarla karşılaşımıştır. Artan nüfus ile birlikte kent yoğunluğu da artış göstermiştir. 1990 yılında 1.15 kişi/ha olan nüfus yoğunluğu 2018 yılında 2.24 kişi/ha olmuştur (TÜiK, 2018).

Kentsel nüfustaki artış ile beraber, park alanlarının miktarındaki artış yetersiz kalmıştır. 2038 çevre düzeni plan raporunda, ilçelerin mevcut nüfusları ve öngörülen nüfusları doğrultusunda yeşil alan miktarındaki artışın yeterli olmadığı saptanmıştır. Bu sebeple özellikle kent merkezinde doluluk-boşluk oranından kaynaklanan kentsel ısı adası etkisi ortaya çıkmaktadır. Yutak alanı olan park alanları nicelik ve dengeli dağılım açısından yetersizdir. Ankara kentinde yoğunluk 1985 - 2002 yılları arasında \% 8,9 oranında artmış, buna karşın yeşil alanlar \% 3,1 oranında artış göstermiştir. Ancak yeşil alan miktarı yoğun yerleşimin olduğu kent merkezinde değil, ODTÜ ormanı gibi çeşitli üniversite ve kamu kuruluşlarına ait alanlarda artmıştır. Dolayısı ile kent merkezinde gecekonduların çok katlı apartmanlara dönüşümü, belli bölgelerde kat sayısının artması gibi nedenlerle yoğunluk artarken yeşil alan miktarı artmamıştır (Yüksel ve Yılmaz, 2008).

\subsection{Demografik ve sosyo-ekonomik özellikleri}

Cumhuriyetin ilanı ve Ankara'nın başkent olması ile birlikte kent metropoliten bir kimlik kazanmaya başlamış ve sonrasında nüfus bakımından İç Anadolu bölgesinin en büyük ve ülkenin ikinci büyük kenti olmuştur. Ankara ili nüfusu 2018 yılı itibariyle 5.503 .985 kişidir. 1975 'li yıllara kadar yükselişte olan nüfus artış hızı, 1975 yılından itibaren düşüş göstermiş, ilk kez 1975-1980 yılları arasında Türkiye nüfus artış hızından düşük bir seviyeye ulaşmıştır. 2012-2013 yıllarındaki nüfus artış hızı Ankara için \%॰15.9, Türkiye için \%॰13.7 olarak gerçekleşerek son yıllarda birbirine en yakın oldukları değerlere ulaşmış, 2013 yılından sonra 2014 ve 2015 yıllarında Türkiye değeri \%o13 seviyesinde kalırken Ankara değeri \%o23 seviyesine çıkmıştır (Ankara Büyükşehir Belediyesi, 2017a). 2008-2018 yılları arasındaki nüfus artış hızı verileri incelendiğinde, nüfusun sürekli arttığı ancak nüfus artış hızında dalgalanmalar yaşandığı görülmektedir.

TUİK verilerine göre, Ankara'da özel araç sahipliliğinde sürekli artış görülmektedir, TMMOB Şehir Plancıları Odası Ankara Şubesi 2007 verilerine göre de, günlük toplam otomobil yolculuğu mesafesi de yıllar içerisinde artmaktadır. Kentsel yayılma ile ortaya çıkan otomobil ağılıklı ulaşım politikaları kat edilmesi gereken mesafeyi de arttırmaktadır. Artan araç sayısı 
çevre kirliği, gürültü gibi pek çok sorunu da beraberinde getirmektedir (Türk Mimar ve Mühendis Odaları Birliği, 2007).

Kalkınma Bakanlığı tarafından yapılan; demografi, eğitim, sağlık, istihdam, rekabetçi ve yenilikçi kapasite, mali kapasite, erişilebilirlik ile yaşam kalitesi olmak üzere 8 alt kategoride hazırlanan İllerin Gelişmişlik Endeksi Sıralamasına göre Ankara ikinci sırada gelmektedir. Ankara'nın gelişmişlik değerleri itibariyle hem Türkiye ortalamasının hem de bölge ortalamasının üzerinde bir performansa sahip olduğu görülmektedir (Ankara Büyükşehir Belediyesi, 2017a).

\subsection{Değerlendirme}

Ankara kentinin bahsedilen tüm yerel özellikleri ışığında; gelecekte öngörülen sıcaklık artışı ve yağış oranlarındaki değişim, saçaklanan makroformu, artan kentsel alan büyüklüğü ve kent merkezindeki yoğunluğa karşın park alanlarının dağılımı ve büyüklüğündeki yetersizlik ve dengesizlik, yutak alanlar üzerindeki kentleşme baskısı ve yutak alan varlığının azalması, yenilenebilir enerji kaynaklarının yeterince değerlendirilememesi ve fosil yakıt kullanım oranı, nüfus büyüklüğü ve nüfus artış hızı, sosyo-ekonomik gelişmişlik düzeyi, buna bağlı gelir durumu, refah seviyesi, taşıt sahiplilik oranı göz önüne alındığında, Ankara kenti için iklim değişikliği azaltım politika ve stratejilerine odaklanmak ya da öncelik vermek gerektiği ortaya çıkmaktadır.

Diğer bir anlatımla, her kent gibi Ankara kenti de sera gazı emisyonundan büyük ölçüde sorumludur. Özellikle bina ve ulaşım sektörleri kentteki sera gazı emisyonuna yol açan sektörlerdendir. Bu kapsamda kentin makroform tipi, ulaşımdan kaynaklı yakıt tüketim miktarı, hanehalkı enerji tüketimi, taşıt sahiplilik oranı, nüfus büyüklüğü ve yoğunluğu, gelir durumu ve refah düzeyi, sosyo-ekonomik gelişmişlik düzeyi gibi faktörler seragazı emisyonu yaratan, orman varlığı ve kentsel yeşil alanlar ise sera gazı emisyonunu azaltan faktörlerdir. Diğer yandan, iklim değişikliği tehditlerine maruz kalacak kentsel yerleşik alan büyüklüğü, nüfus yoğunluğu, nüfus büyüklüğü, savunmasız nüfus vb. arttıkça kırılganlık düzeyi artmakta, buna karşılık, gelir durumu ve refah düzeyi, sosyo-ekonomik gelişmişlik düzeyi, kentsel yeşil alan, sağlık, altyapı hizmetlerine erişim vb. artıkça kırılganlık azalmakta veya kentin adaptasyon kapasitesi artmaktadır. Yukarıda açıklanan özellikleri doğrultusunda, Ankara kentinin iklim değişikliği tehditleriyle ve olumsuz etikleriyle karşı karşıya olduğu, sera gazı emisyonunu arttıran faktörlere sahip olduğu, bu bakımdan iklim değişikliğine karşı dirençli bir kent olmadığı, adaptasyon kapasitesini arttırmanın gerekliliğiyle birlikte, sera gazı azaltım politikalarının kentin direnç kazanmasında asli unsur olduğu, dolayısıyla "iklim direnci" temasını kentsel politikalara ve arazi kullanım planlamasına dahil etmenin önemli ve gerekli olduğu düşünülmektedir.

\section{ANKARA ÇEVRE DÜZENI PLANI VE ANKARA NAZIM IMAR PLANININ DEĞERLENDIRIILMESİ}

Ankara kenti için iklim değişikliği azaltım politika ve stratejilerinin öncelikli olması gerekliliğinden hareketle, Ankara kentinin mevcut planlarının iklim değişikliğine dirençliliği, diğer bir ifadeyle, azaltım politika ve stratejilerinin arazi kullanım politika ve planlarına ne ölçüde yansıdığı irdelenmelidir.

İklim dirençli kentler inşa edebilmek için iklim değişikliğine neden olan etkenleri belirleyip kontrol altına almak ve azaltmaya yönelik önlemler geliştirmek temel politikalardan biridir. $\mathrm{Bu}$ kapsamda; iklim değişikliğine neden olan sera gazı salınımlarını azaltma politikaları konusunda Hükümetlerarası İklim Değişikliği Paneli (IPCC) raporları incelendiğinde; sektörel temelli azaltıma önem verildiği, enerji, ulaşım, konut, sanayi, tarım, ormancılık ve diğer arazi kullanımı bağlamlarında sektörler arası azaltma önlemlerinin geliştirildiği görülmektedir. 
Azaltım politikaları kurumlar, ulusal ve bölgesel düzeyde işbirlikleri ve kalkınma stratejileri ile birleştirilmiştir. Kentsel alanların küresel enerji kullanımının ve enerji kaynaklı $\mathrm{CO}_{2}$ emisyonlarının yarısından fazlasını oluşturduğu, kentlerdeki kişi başı emisyon miktarının her kente özgü fiziksel, ekonomik ve sosyal faktörler gibi pek çok değişkenden etkilendiği vurgulanmaktadır (IPCC, 2014).

İlgili literatürde iklim değişikliği azaltım politikalarını ele alan çalışmalarda azaltım; enerji, ulaşım, konut gibi sektörler (örn. Wright ve Fulton, 2005; Sengupta, 2008; Dulal vd., 2011) ya da yutak alanlar (yeşil altyapı gibi) özelinde (örn. Gunawerdana vd., 2017), kentsel ISı adası (Brianstone, 2009; Oliveira vd., 2011) bağlamında incelenmiş, kentsel planlamayla entegrasyonunun önemine vurgu yapılmış (örn. Sılaydın ve Çukur, 2012), "düşük karbon kentler" temasıyla ilişkilendirilmiş (örn. Liu ve Deng, 2011; Cao ve Li, 2011; Moriartya ve Wang, 2014; Sahni ve Aulakh, 2014), kent makroformuna ilişkin öneriler (kompakt kent) (Tuğaç, 2018) geliştirilmiştir.

Söz konusu azaltım politika ya da stratejilerinin uygulanmasında kentsel planlama önemli bir araçtır. Örneğin, enerji-etkin yapılaşma, motorlu taşıt yolculuk süresini kısaltma, toplu taşınım olanaklarının geliştirilmesi, bisiklet ve yaya erişiminin arttırılması, kompakt kentsel form ve karma kullanımlı yapılaşma, karbon yutak alanlarının artırılması gibi kentsel seragazı emisyonunu azaltan politika ve stratejiler yerel ölçekte kent planlamayla entegre edilebilir. Bu bağlamda bir sonraki başlıkta, Ankara çevre düzeni planı ve nazım imar planının iklim değişikliğini göz önüne alıp almadığı, iklim direnci teması çerçevesinde sera gazı emisyonlarını azaltmayı ne ölçüde desteklediği incelenecektir.

\subsection{1/100.000 Ölçekli Ankara Çevre Düzeni Planının değerlendirilmesi}

1/100.000 ölçekli Ankara Çevre Düzeni Planı, Ankara Büyükşehir Belediye Meclisi'nin 13.01.2017 tarih ve 116 sayılı karar numarası ile onaylanmıştır. Planının açıklama raporunda planın "yaşanan hızlı nüfus artışına paralel olarak gelişen kentleşme ve sanayileşmenin kontrollü olarak gelişmesini, yaşanan gelişmelerin sürdürülebilir ve ekolojik dengeye zarar vermeden yaşanılabilir bir çevre ile uyumlu hale getirilmesini, tarihi, kültürel ve doğal değerlerin koruma-kullanma dengesi gözetilerek korunmasını ve geliştirilmesini, Türkiye'nin ülke bütününde belirlenen kalkınma hedeflerine uygun olarak tüm sektörlerde planlı bir şekilde büyümeyi" amaçladığı belirtilmiştir.

Plan, Ankara il sınırını kapsamaktadır (Şekil 5). Plan hedefleri bakımından ele alındığında; çevreye duyarlı ve doğal kaynakların korunduğu, kent merkezindeki yoğun yapılaşmanın çeperlere doğru yayılmasını sağlayıcı önlemler getirildiği, enerji, su ve kaynak verimliliğinin sağlandığı, gürültü, toprak ve su kirliliğini önleyici kararlar alındığı, su kullanımında dengenin gözetildiği bir kent amaçlandığı görülmektedir.

1/100.000 ölçekli 2038 Ankara Çevre Düzeni Planı plan açıklama raporunda, iklim değişikliği kapsamında; gerek Ankara'nın yağış verileri ile sıcaklık değerlerindeki değişimler gerekse iklim değişikliği ile ilgili ulusal ve küresel ölçekli öngörüler doğrultusunda Ankara'nın orta vadede iklim değişikliğine bağlı ortaya çıkacak olan kuraklık ve ona bağlı sorunlar ile karşıllaşmasının beklendiği, Ankara'da iklim değişikliği konusu ile ilgili göstergelerin uzun dönemde bazı değişimlerin yaşandığını gösterdiği, yıllık ortalama sıcaklıkların arttığı, konularına vurgu yapılmıştır. 


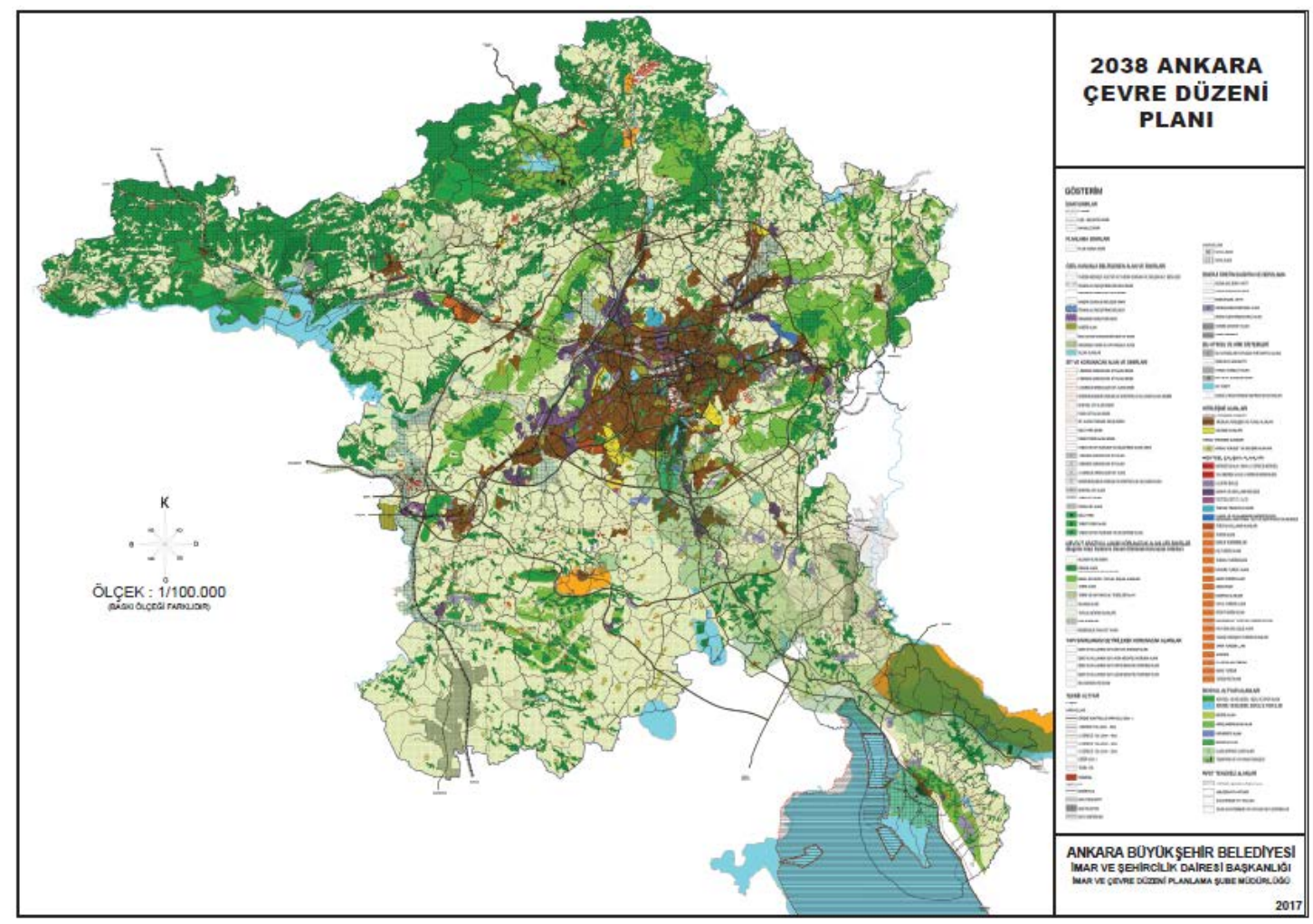

Şekil 3. 2038 Ankara çevre düzeni planı (Ankara Büyükşehir Belediyesi, 2017b)

1/100.000 ölçekli 2038 Ankara Çevre Düzeni Planında iklim değişikliği ile ilgili alınması gerekli önlemler kapsamında;

- İlgili kurum ve kuruluşlarca "İklim Risk Yönetimi" ve Ankara için "İklim Değişikliği ile Mücadele Eylem Planı" hazırlanması gerektiğinin düşünüldüğü,

- Çevre dostu ulaşımın yaygınlaştırılması (mevcut ulaşım altyapısının güçlendirilmesi ve ulaşım türleri arasında entegrasyonun sağlanması, raylı sistem ve toplu taşımacılığın özendirilmesi),

- Enerji kullanımında yenilenebilir enerjinin payının artırılması ("Yenilenebilir Enerji Kaynak Yönetim Planı" oluşturulması),

- Emisyonların ve atıkların sınırlandırıması,

- Ankara genelinde elektrik dağıtım kayıpları ve israfının azaltılması için önlemler alınması; ısı yalıtımı, akıllı enerji sistemleri kullanımı, pasif ısıtma, soğutma ve aydınlatma mekanizmaları gibi enerji verimliliği konusunda bilgilendirme faaliyetleri yürütülmesi,

- Sanayi sektöründe sera gazı emisyonlarının azaltımasına yönelik eğitim ve bilinçlendirme çalışmaları yapılarak, üretim sistemlerinin bu doğrultuda planlanması,

- Su kaynaklarının etkin kullanımı, kayıp kaçak ve israfların önüne geçilmesi konularında gerekli teknik çalışmalar ile bilinçlendirme faaliyetlerinin yürütülmesi gerektiği, kamu kurumları ile ticari işletmelerde su sarfiyatının azaltııması için standardizasyon ve yaptırım mekanizmalarının geliştirilmesi gerektiği vb. öneriler sıralanmıştır. Ayrıca, yutak alanlardan orman alanları ve yeşil alanların artırımasına yönelik planlama hedeflerinin (örn. mevcut orman varlığına ilaveten ormana dönüşecek alan statüsünde "Ağaçlandıılacak Alan" önerisiyle \% 7 lik bir artış sağlanarak Ankara orman varlığının arttırılması) de belirlendiği görülmektedir.

Planda, kentte koruma ve planlama ilkeleri bakımından koruma-kullanma dengesinin sağlanması, kentin gelişiminin belirli bir alanda yoğunlaşmak yerine çeperlere dağıtılması gibi ilkeler yer almaktadır. Kent içi ulaşım, çevre sorunları gibi sorunlar önceli sorunlar olarak 
ele alınmıştır. Kentsel risk ve tehditler doğal afetlerle sınırlandırılmıştır. Dolayısıyla, 1/100.000 ölçekli Ankara Çevre Düzeni Planının sera gazı emisyonu azaltım politikalarını ele almakla birlikte, iklim direncini odağına almadığı değerlendirilmektedir.

\subsection{1/25.000 Ölçekli Ankara Nazım İmar Planının değerlendirilmesi}

Ankara 1/25.000 ölçekli nazım imar planı 16.02.2007 tarihinde onaylanmış ve çeşitli itirazlar doğrultusunda değişikliklere gidilerek kabul edilmiştir (Şekil 6). Plan raporunda kentin dört kuşak olarak ele alındığı belirtilmiştir. 1.kuşak olarak belirlenen bölgede Ankara'yı çevreleyen doğal eşikler dikkate alınmıştır. 2. kuşak bölgesi ilk bölge ile benzer topografik çanak yapısı ile kentin temel rekreatif gereksinimlerinin karşılandığı ve kent merkezinden 50$90 \mathrm{~km}$ uzaklıkta kalan alanları tanımlamaktadır. 3. kuşak bölgesi kentsel nüfusun en yoğun olduğu ve ana çanak olarak tanımlanan alanı içermektedir. 4. kuşak bölgesi de kent içinde sürekliliğini korumayan park ve bahçeler olarak tanımlanmıştır.

Plan raporunda, Ankara'nın saçaklanan makroformuna ve artan kentsel alan büyüklüğüne bağlı olarak kent içi ulaşımının da şekillendiği, bunun sonucunda artan araç ve yolcu sayıları nedeniyle yeni planlama yaklaşımlarının gerektiği belirtilmiştir. Raporda iklim değişikliğine yönelik bir değerlendirme getirilmemiştir. Ancak iklim değişikliği ile ilişkilendirilebilecek bazı önerilerin yer aldığı görülmektedir. Örneğin;

- 80'li yıllardan bu yana, ana çanakta sıkıştığı ve tanımlanmış odaklara desantralize edilmesi gerektiği yönündeki tespitlere karşın, gerçek bir desantralizasyondan çok bir kentsel yayılma-saçılma yaşayan Ankara'da, kent ve kamu kaynaklarının etkin kullanımına olanak sağlayacak bütünleşik kompakt makroform seçeneklerini araştırmak,

- Ankara kent bütününden kopuk olarak gelişmiş ve 5216 Sayılı Kanun ile Büyükşehir Belediyesine bağlanmış belediyelerin, tarım topraklarına, su havzalarına yayılan plan ve uygulamalarının, sürdürülebilirlik, koruma, kent ve kamu kaynaklarını etkin değerlendirme, bilimsel-teknik gereklere oturma ilkeleri bağlamında revizyonunu gerçekleştirmek,

- Kent makroformunun kompakt yapısı içindeki sorun alanlarını tespit ederek, bu bölgelerde özgün müdahale biçimleri geliştirmek, gerekli kentsel yenileme ve dönüşümleri, gereğinde afet öncelikli proje ve müdahaleleri gerçekleştirmek,

- Kentsel makroform içinde açık-yeşil alan sistemini temel bir unsur olarak kurgulayıp, kent için havalanma koridorları yaratmak, bu sistemi olası afetler için yaratacağı potansiyelleri bağlamında değerlendirmek,

- Parçacı ve noktasal yayılmalarla kentin makroformunu yağ lekesi biçimine sokan eğilimleri engelleyecek, kamu kurumları, geniş alan kullanışları, açık yeşil alanlar vb. kullanım kararlarını, makroformun temel unsurları olarak tanımlamak,

- Hava kirliliğinin önlenebilmesine yönelik yer seçimleri, makroform seçeneklerini değerlendirmek,

- Alternatif enerji potansiyellerini (su, güneş, rüzgar vb.) araştırarak, bunların kentsel yaşamın her alanında etkin biçimde kullanılmasını sağlayarak, küresel ısınma yaratan unsurları minimize etmek. 


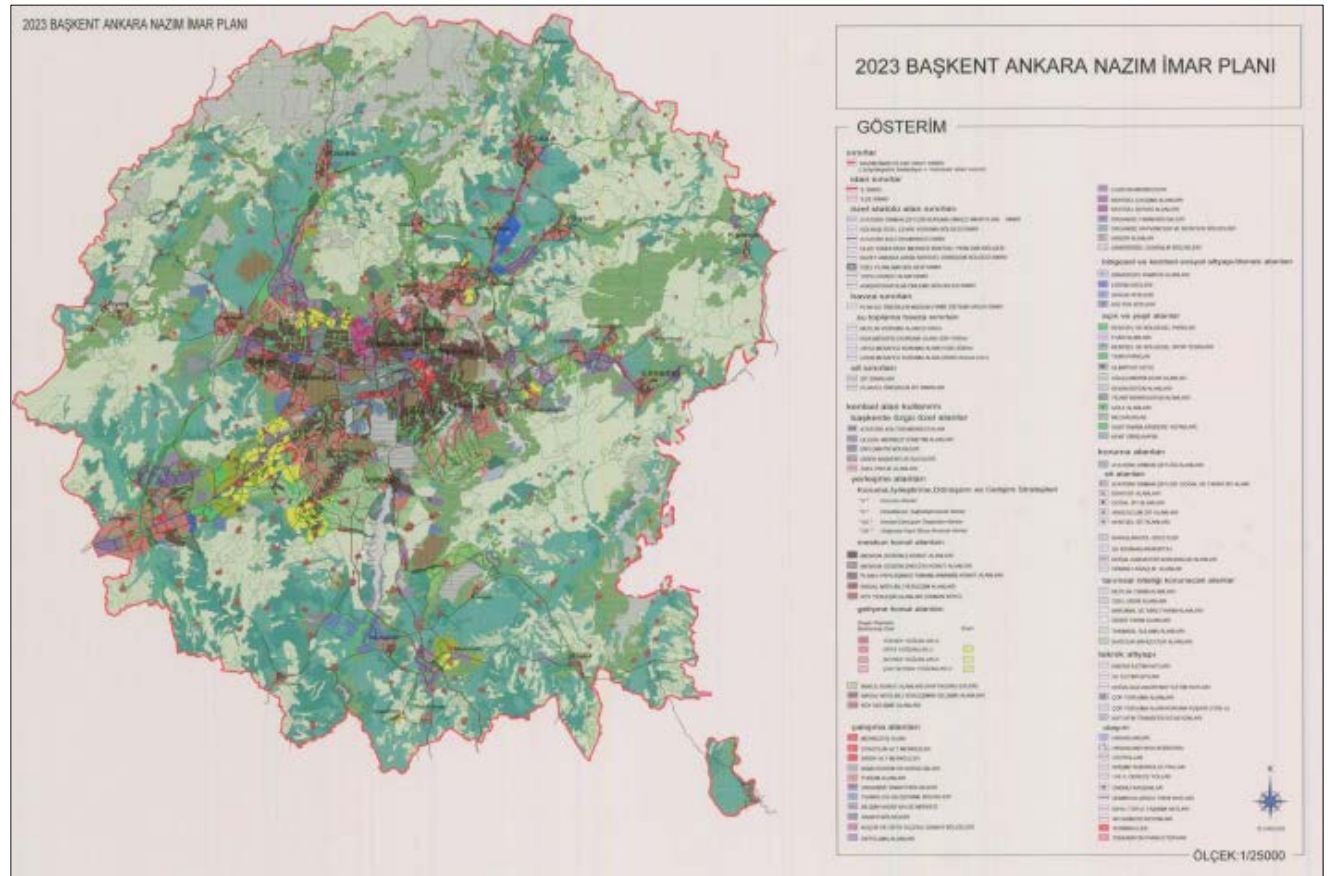

Şekil 4. 2023 Başkent Ankara Nazım İmar Planı (Ankara Büyükşehir Belediyesi, 2007)

\section{SONUÇ VE DEĞERLENDİRMELER}

Kentlerin iklim değişikliğine direnç oluşturabilmesi bağlamında kent planlamaya azaltım ve adaptasyon politikalarının dahil edilmesi, bununla birlikte, her kentin fiziksel, çevresel, morfolojik ve sosyo-ekonomik özellikleri itibariyle mekânsal planlarında söz konusu politikaları birlikte ele almakla birlikte, birine öncelik vermesi gerektiği düşünülmektedir. Kentsel direnç oluşturabilme ya da dirençlilik kazandırabilme politikalarının nasıl önceliklendirileceğine ilişkin kararlara ulaşabilmek, öncelikle mevcut ve gelecekteki risklerin anlaşıımasını gerektirir. Bu da risk esaslı arazi kullanım planlamasına işaret eder. Risk değerlendirmeleri, potansiyel etkileri belirlemek, ölçmek ve risk azaltma önlemlerine öncelik vermek için bir temel sağlar (Jha, vd., 2013). Bu bağlamda arazi kullanım planlamasında riskleri azaltmaya yönelik kentin gelişim yönü ve büyüklüğü, arazi kullanım türü, altyapı ve ulaşım sistemi kararları, nüfus yoğunlukları vb. belirlenebilir.

Makalede, Ankara kentinin iklim değişikliğine dirençli hale gelebilmesi için, sera gazı azaltım politika ve stratejilerine öncelik verilmesinin önemi ortaya konulmuş ve azaltım politikalarının mekânsal planlarla bütünleştirilmesi gerekliliğinden yola çıkılarak, Ankara üst ölçek mekânsal planları risk azaltımı çerçevesinde incelenmiştir. Bu kapsamda Ankara Çevre Düzeni Planının iklim değişikliği konusunda Ankara Nazım İmar Planına göre daha duyarı olduğu, ulaşım, enerji, sanayi sektörleri özelinde önlemler geliştirmeyi hedeflediği, iklim değişikliği konusunda ilgili kurum ve kuruluşların sorumluluk, görev ve işbirliklerini tanımlayıcı eylem planlarının önemine dikkat çektiği, ancak yutak alanlar konusunu yeterince ele almadığı değerlendirilmektedir. Ankara Nazım İmar Planında ise yağ lekesi şeklinde yayılan kent makroformuna yönelik müdahaleler, yenilenebilir enerji kaynaklarının etkin kullanımı gibi konulara vurgu yapıldığı, ancak doğrudan iklim değişikliğinin temel bir sorun olarak ele alınmadığı görülmektedir. Kısaca, Ankara üst ölçek mekânsal planlarının iklim değişikliği riskini esas alan planlar olmadığı, dolayısıyla Ankara kentinin iklim değişikliğinden kaynaklı tehlikelere karşı yeterince dirençli olmadığı değerlendirilmektedir.

Ankara kentinin iklim değişikliğinden kaynaklı belirsizliklere ve beklenmedik gelişmelere karşı dirençli olabilmesi, diğer bir ifadeyle, Ankara kenti için iklim değişikliği risk, tehdit ve 
etkilerinin azaltılması / hafifletilmesi (böylece sistemin sağlamlığının arttırılması) bağlamında yapılması gerekenler; Ankara kenti için sera gazı emisyon envanterinin sektörler özelinde belirlenmesi, iklim değişikliği öngörülerine da dayanarak risk haritalarının ve risk eylem planının oluşturulması, bu veriler ve "iklim direnci" göz önüne alınarak sera gazı emisyonunun azaltılmasına ya da dengelenmesine yönelik iklime duyarlı plan kararlarının (yutak alanların korunması ve artırılması, kent makroformunun yayılmasını sınırlandırıcı kararlar, ulaşım türleri arasında entegrasyonun sağlanması, yenilenebilir enerji kaynaklarından yararlanılması, vb.) geliştirilmesi şeklinde sıralanabilir.

Ankara kentinin iklim değişikliğinden kaynaklı belirsizliklere ve beklenmedik gelişmelere karşı dirençli olabilmesi, diğer bir ifadeyle, uyumun sağlanması (sistemin kendini düzeltme hızının arttırılması) bağlamında yapılması gerekenler ise; kırılgan sektörlerin, grupların, doğal ve kültürel değerlerin vb. analiz edilmesi, enerji, sanayi, bina, ulaşım gibi sektörler ile, altyapı ve hizmetlere erişim, kuraklık risk yönetimi, su yönetimi, gıda güvenliği, halk sağlığı gibi alanlarda uyum eylem planlarının hazırlanması olarak sıralanabilir. 


\section{KAYNAKLAR}

Albers, M., Deppisch, S., (2013). Resilience İn The Light Of Climate Change: Useful Approach Or Empty Phrase For Spatial Planning?, European Planning Studies, 21(10), 1598-1610.

Ankara Büyükşehir Belediyesi. (2007). 2023 Başkent Ankara nazım imar planı açıklama raporu,

Erişim adresi: https://www.ankara.bel.tr/ankara-buyuksehir-belediyesi-nazim-plan/

Ankara Büyükşehir Belediyesi. (2017a). 2038 Ankara çevre düzeni planı açıklama raporu, Erişim adresi: https://www.ankara.bel.tr/Plan_Aciklama_Raporu/plan_aciklama_raporu.html

Ankara Büyükşehir Belediyesi. (2017b). 2038 Ankara çevre düzeni planı açıklama raporu, Erişim adresi: https://www.ankara.bel.tr/files/5915/2766/6564/Pafta.pdf

Ankara Kalkınma Ajansı. (2013a). İstatistiklerle Ankara 2013,

Erişim adresi: https://www.ankaraka.org.tr/tr/istatistiklerle-ankara-2013_1875.html

Ankara Kalkınma Ajansı. (2013b). 2014-2023 Ankara bölge planı,

Erişim adresi: http://www3.kalkinma.gov.tr/DocObjects/view/15312/TR51_ankara-bolge-plani 2014-2023-taslak_(1).pdf

Brianstone, JR. (2009), Land Use As Climate Change Mitigation, Environmental Science \& Technology, 43, 9052-9056.

Cao, S., Li, C. (2011), The Exploration Of Concepts and Methods For Low-Carbon Eco-City Planning, Procedia Environmental Sciences, 5, 199-207.

Çevre ve Şehircilik Bakanlığı. (2017), Ankara ili 2017 yılı çevre durum raporu. Erişim adresi: https://webdosya.csb.gov.tr/db/ced/icerikler/2017_ankara_cevre_durum_raporu_son20181003143741.pdf

Çobanyılmaz, P., Yüksel D. Ü. (2013), Kentlerin İklim Değişikliğinden Zarar Görebilirliğinin Belirlenmesi: Ankara Örneği, Süleyman Demirel Üniversitesi Fen Bilimleri Enstitüsü Dergisi, 17(3), 39-50.

Denton, F., Wilbanks, T. J., Abeysinghe, A. C., Burton, I., Gao, M. C., Lemos, T., Masui, K. L., Brien, O., Warner, K. (2014), Climate-Resilient Pathways: Adaptation, Mitigation, And Sustainable Development In Climate Change: Impacts, Adaptation, And Vulnerability. Part A: Global And Sectoral Aspects. Contribution Of Working Group II To The Fifth Assessment Report Of The Intergovernmental Panel On Climate Change. Cambridge University Press, Cambridge, United Kingdom and New York, USA, 1101-1131.

Dulal, H. B., Brodnig, G., Onoriose, C. G. (2011), Reducing Climate Change In Transportation Sector By Urban Planning: A Review. Habitat International, 35, 494-500.

Durmaz, B., Erçetin, C. (2012), Dirençlilik (Resilience) Konsepti Altında Ankara'daki Kentsel Saçaklanmanın Ekolojik Boyutunun İncelenmesi. KBAM 3. Kentsel ve Bölgesel Araştırmalar Sempozyumu, 'Kent Bölgeler, Metropoliten Alanlar ve Büyükşehirler: Değişen Dinamikler ve Sorunlar' Bildiri Kitabı, (s. 451-470), Ankara. 
Godschalk, D. R., 2003, Urban Hazard Mitigation: Creating Resilient Cities. The Natural Hazards Review, 4(3), 136-143.

Gunawardena, K. R., Wells, M. J., Kershaw, T. (2017), Utilizing The Green and Blue Area To Reduce Urban Heat Density. Science of the Total Environment 584-585, 1040-1055.

Hamin, E. M., Gurran, N. (2009), Urban Form And Climate Change: Adaptation And Reduction Of Adaptation In The Usa And Australia, Habitat International, 33, 238-245.

Intergovernmental Panel on Climate Change, Working Group III. (2014), Climate change 2014: mitigation of climate change,

Erişim adresi: https://www.ipcc.ch/site/assets/uploads/2018/02/ipcc_wg3_ar5_full.pdf

Jha, A., Miner, T., Geddes, Z., (2013), Building Urban Resilience Principles, Tools, and Practice, Washington: Directions in Development.

Leichenko, R., (2011), Climate Change And Urban Resilience, Current Opinion in Environmental Sustainability, 3(3), 164-168.

Liu, J., Deng, X. (2011), The Effects Of Climate Change On Chinese Cities And Reduction, Current Opinion in Environmental Sustainability, 3, 188-192.

Moriarty, P., Wang, S. J. (2014), Low-Carbon Cities: Lifestyle Changes Are Necessary, Energy Procedia, 61, 2289-2292.

Nordhaus, W. D. (1993), Reflections On The Economics Of Climate Change, Journal Of Economic Perspectives, 7 (4), 11-25.

Normandin, J.M., Therrien, M.C. ve Tanguay, G.A., (2009), City Strength in Times Of Turbulance: Strategic Resilience Indicators, Joint Conference on City Futures, Madrid, 4-6 June, 2009

Oliveira, S., Andrade, H., Vaz, H. (2011), Cooling Effect Of Green Areas As Contribution To Urban Heat Reduction: A Case Study In Lisbon, Building and Environment, 46, 2186-2194.

Sahni, S., Aulakh, R. S. (2014), Planning For Low Carbon Cities In İndia. Environment and Urbanization Asia, 5(1), 17-34.

Sengupta, N. (2008), Use Of Cost-Effective Construction Technologies In India To Mitigate Climate Change. Current Science, 94(1), 38-43.

Sharifi, A., Yamagata, Y., (2014), Resilient Urban Planning: Major Principles and Criteria. Energy Procedia, 61(1), 1491-1495.

Sılaydın Aydın, M. B., Çukur, D. (2012), Yerleşim Bölgelerindeki Karbon-Oksijen Dengesini Korumak: Arazi Kullanım Planlaması İçin Bir Yöntem Önerisi, Urban Forestry \& Urban Greening, 11, 87-94.

Sılaydın Aydın, B., Kahraman, E. D. (2017), İklim Değişikliği Azaltım ve Adaptasyon Stratejilerinin Türkiye İllerine (Merkez Kentler) Göre Önceliklendirilmesi. Dokuz Eylül Üniversitesi Bilimsel Araştırma Projesi Raporu, Proje No: 2015.KB.FEN.006. 
Tuğaç, Ç. (2018), Türkiye İçin İklim Değişikliğine Dayalı Kentsel Planlama Modeli Önerisi: Eko-Kompakt Kentler, Atatürk Üniversitesi Iktisadi ve Idari Bilimler Dergisi, 32(4), 10471068.

Türk Mühendis ve Mimar Odaları Birliği. (2007), Ankara'da Ulașımın Geleceği Karanlık!. Planlama Dergisi, 39, 5-10.

Türkiye İstatistik Kurumu. (2018), Adrese dayalı nüfus kayıt sistemi sonuçları.

Erişim adresi: https://biruni.tuik.gov.tr/medas/?kn=95\&locale=tr

Wright, L., Fulton, L. (2005), Climate Change Mitigation and Transport in Developing Nations, Transport Reviews, 25 (6), 691-717.

Yüksel D. Ü., Yılmaz, O. (2008), Ankara Kentinde Kentsel Isı Adası Etkisinin Yaz Aylarında Uzaktan Algılama ve Meteorolojik Gözlemlere Dayalı Olarak Saptanması ve Değerlendirilmesi. Gazi Üniversitesi Mühendislik Mimarlık Fakültesi Dergisi, 23 (4), 937952. 